\title{
PERAN BUDAYA ORGANISASI MEMEDIASI PENGARUH KEPEMIMPINAN TRANSFORMASIONAL TERHADAP PEMBERDAYAAN PSIKOLOGIS
}

\author{
Ni Made Mas Anindya Sthira Sista ${ }^{1}$ \\ I Wayan Mudiartha Utama ${ }^{2}$
}

\author{
${ }^{1,2}$ Fakultas Ekonomi dan Bisnis Universitas Udayana (Unud), Bali, Indonesia \\ e-mail: sthirasista08@gmail.com
}

\begin{abstract}
ABSTRAK
Pemberdayaan psikologis merupakan keyakinan pegawai akan kemampuannya dalam proses menangkap dan mengerti keadaan lingkungan organisasi sebagai tindakan motivasi terhadap pegawai yang berhubungan dengan keterampilan dan kompetensi yang dimiliki. Tujuan penelitian ini adalah untuk mengetahui pengaruh kepemimpinan transformasional terhadap pemberdayaan psikologis, pengaruh kepemimpinan transformasional terhadap budaya organisasi, pengaruh budaya organisasi terhadap pemberdayaan psikologis dan peran budaya organisasi memediasi pengaruh kepemimpinan transformasional terhadap pemberdayaan psikologis. Penelitian ini dilakukan di Dinas Perindustrian dan Perdagangan Kota Denpasar. Jumlah sampel yang diambil 50 pegawai kontrak yang sudah bekerja minimal 1 tahun, dengan metode sampel jenuh. Pengumpulan data dilakukan melalui wawancara dan observasi. Teknik analisis data yang digunakan adalah analisis jalur (path analysis). Hasil penelitian menunjukan bahwa kepemimpinan transformasional berpengaruh positif dan signifikan terhadap pemberdayaan psikologis, kepemimpinan transformasional berpengaruh positif dan signifikan terhadap budaya organisasi, budaya organisasi berpengaruh positif dan signifikan terhadap pemberdayaan psikologis dan peran budaya organisasi memediasi kepemimpinan transformasional terhadap pemberdayaan psikologis.

Kata Kunci: pemberdayaan psikologis, kepemimpinan transformasional, budaya organisasi
\end{abstract}

\begin{abstract}
Psychological empowerment is the employee's confidence in his ability in the process of capturing and understanding the state of the organization's environment as an act of motivation towards employees that relates to the skills and competencies they have. The purpose of this study was to determine the effect of transformational leadership on psychological empowerment, the influence of transformational leadership on organizational culture, the influence of organizational culture on psychological empowerment and the role of organizational culture to mediate the influence of transformational leadership on psychological empowerment. This research was conducted at the Office of Industry and Trade in Denpasar City. The number of samples taken was 50 contract employees who had worked for at least 1 year, with a saturated sample method. Data collection is done through interviews and observations. The data analysis technique used is path analysis. The results showed that transformational leadership has a positive and significant effect on psychological empowerment, transformational leadership has a positive and significant effect on organizational culture, a positive and significant organizational culture influences psychological empowerment and the role of organizational culture mediates transformational leadership on psychological empowerment.

Keywords: psychological empowerment, transformational leadership, organizational culture
\end{abstract}


Ni Made Mas Anindya Sthira Sista, Peran Budaya Organisasi...

\section{PENDAHULUAN}

Suatu organisasi di dalam usahanya untuk mencapai tujuan yang telah direncanakan sangat tergantung pada berbagai faktor yang mempengaruhinya. Salah satu faktor yang mempengaruhinya adalah sumber daya manusia yang memiliki peranan penting di segala kegiatan organisasi. Tanpa adanya sumber daya manusia organisasi tidak dapat melaksanakan dan menjalankan aktivitas organisasinya. Dalam hal ini tenaga kerja merupakan sumber yang sangat penting dalam suatu organisasi yang mana nantinya diharapkan dapat berpartisipasi dan menyumbangkan tenaganya dengan penuh kesungguhan dan tanggung jawab, sehingga diperlukan perberdayaan psikologis.

Pemberdayaan psikologis adalah keyakinan seorang individu akan kemampuannya untuk melakukan kegiatan kerja terkait dengan keterampilan dan kompetensi (Fadhila, 2012). Pemberdayaan psikologis bukanlah kepribadian tetap, karena terdiri dari keyakinan seseorang tentang sesuatu yang didapatkan dari proses berpikir tentang seseorang atau sesuatu yang dibentuk oleh lingkungan kerja (Stander dan Rothmann, 2010). Pemberdayaan psikologis sebagai proses menangkap dan mengerti keadaan sekitar untuk selalu aktif memberikan energi, mendorong dan menyalurkan perilaku ke arah mencapai kebutuhan untuk memberi kepuasan, yang berkaitan dengan peran kerja (Boudrias et al., 2014).

Pemberdayaan psikologis adalah pendekatan baru untuk memotivasi dan telah mendapatkan perhatian besar dari para pemimpin (Edalatian et al., 2013). Pemberdayaan psikologis dianggap penting sebagai salah satu tindakan motivasi terhadap pegawai agar dapat melakukan pekerjaan seefektif mungkin (Gunawan 
dan Viyanita, 2012). Pencapaian tujuan organisasi menjadi tidak layak tanpa memberdayakan pegawai secara psikologis (Ugwu et al., 2014). Dengan demikian pemberdayaan psikologis pegawai meliputi pemberdayaan dari keinginan, kepercayaan, keyakinan dan komunikasi diantara pegawai-pegawai yang bersangkutan (Bandura, 2006:89).

Maulizar (2012), menyatakan bahwa pemimpin transformasional adalah pemimpin yang memotivasi bawahannya untuk bekerja demi mencapai target organisasi serta memuaskan pegawai. Kepemimpinan transformasional merupakan suatu usaha yang dilakukan oleh seorang pemimpin untuk mampu memengaruhi dan mengarahkan seseorang atau kelompok agar dapat mengerjakan kewajiban sesuai dengan wewenang yang telah diberikan oleh pemimpinnya dalam mencapai segala visi dan misi organisasi (Paulsen et al., 2013). Studi yang dilakukan oleh Kurnaz dan Arslan (2011) menunjukkan bahwa pimpinan yang menggunakan gaya kepemimpinan transformasional secara signifikan menghubungkan ke arah psikologis memberdayakan sesama pegawainya. Bass et al. (1987), menyatakan bahwa ada hubungan positif dan signifikan antara kepemimpinan transformasional dan pemberdayaan psikologis.

Habib et al. (2014), menyatakan bahwa secara spesifik budaya organisasi dalam suatu organisasi akan ditentukan oleh kondisi kerjasama tim, kepemimpinan dan karakteristik organisasi yang berlaku di organisasi tersebut. Budaya organisasi adalah sistem nilai yang diyakini, dipelajari, diterapkan dan dikembangkan oleh semua anggota organisasi, sebagai kekuatan untuk mencapai tujuan organisasi (Raf dkk. 2014: 6). Belias dan Koustelios (2014), juga mendefinisikan bahwa budaya 
Ni Made Mas Anindya Sthira Sista, Peran Budaya Organisasi...

organisasi adalah pola berpikir yang dianggap benar atau dugaan yang diterima sebagai dasar untuk mengatasi masalah eksternal dan internal. MacIntosh (2010), menyatakan bahwa efek dari pelaksanaan budaya organisasi adalah pada sikap dan perilaku pegawai serta kinerja organisasi, hal ini menunjukkan bahwa budaya organisasi bertindak sebagai sistem kontrol dan dapat mempengaruhi sikap dan perilaku pegawai melalui nilai-nilai dan keyakinan yang dijalankan di sebuah organisasi.

Pemimpin transformasional merupakan pemimpin yang memotivasi untuk mendorong bawahannya menjadi bagian dari budaya organisasi (Evelyn dan Elegwa, 2015). Bass et al. (2003), dalam temuan penelitiannya telah menegaskan pentingnya kepemimpinan transformasional sebagai tolak ukur budaya organisasi. Para pemimpin membangun tim, menciptakan kesatuan, dan menyelesaikan perselisihan di tingkat kelompok, dan pada akhirnya pemimpin membangun budaya dan menciptakan perubahan dalam organisasi (Nurjanah, 2008). Mengenai hubungan antara kepemimpinan transformasional dan budaya organisasi, menunjukkan bahwa kepemimpinan transformasional secara langsung mempengaruhi budaya organisasi (Lee dan Cho, 2018).

Johnson (2009), berpendapat bahwa budaya organisasi membentuk organisasi dan memberikan pemahaman yang lebih baik, seperti pemberdayaan dan telah menyarankan bahwa budaya organisasi yang tepat meningkatkan proses pemberdayaan psikologis dalam organisasi. Budaya di mana pegawai memiliki hak dan kewajiban untuk berpartisipasi cenderung menciptakan kondisi yang menguntungkan dalam peningkatan pemberdayaan psikologis (Pareek, 2002:173). 
Sotirofski (2014), yang menyatakan bahwa budaya organisasi yang mendukung untuk berubah adalah salah satu faktor penting yang dapat mempengaruhi pemberdayaan psikologis.

Rabindra et al. (2017), menyatakan bahwa budaya organisasi secara signifikan memediasi hubungan antara kepemimpinan transformasional dan pemberdayaan psikologis. Waldman dan Yammarino (1999), menunjukkan bahwa ada hubungan positif dan signifikan yang ada antara kepemimpinan transformasional dan pemberdayaan psikologis. Di dukung juga dengan penelitian yang dilakukan oleh Sotirofski (2014), yang menyatakan bahwa budaya organisasi yang mendukung untuk berubah adalah salah satu faktor penting yang dapat mempengaruhi pemberdayaan psikologis. Hasil penelitian yang telah dilakukan oleh Husein (2018), menunjukan bahwa budaya organisasi dapat memediasi pengaruh kepemimpinan transformasional terhadap pemberdayaan psikologis.

Dinas Perindustrian dan Perdagangan Kota Denpasar merupakan salah satu dinas milik pemerintah kota Denpasar yang memiliki tugas untuk melakukan kegiatan dalam bidang perindustrian dan perdagangan serta memberdayakan usaha kecil menengah, pasar tradisional maupun kegiatan tera timbangan khususnya pada kota Denpasar. Berdasarkan hasil penyebaran kuesioner yang dilakukan kepada 10 orang pegawai kontrak yang sudah bekerja minimal 1 tahun, terdapat beberapa masalah dari indikator pemberdayaan psikologis yaitu diketahui 6 orang pegawai kontrak dominan merasa kurang setuju karena pegawai merasa belum terlibat dalam kegiatan organisasi seperti, beberapa pegawai kurang diikutsertakan dalam kegiatan organisasi, contohnya kegiatan denfest ataupun bookfair yang mana beberapa 
Ni Made Mas Anindya Sthira Sista, Peran Budaya Organisasi...

pegawai kurang diikutsertakan, walaupun ada dalam 1 bidang pekerjaan, dan pekerjaan belum tepat dengan jenjang pendidikan pegawai seperti, pekerjaan yang dipilih pemimpin belum sesuai dengan jenjang pendidikan pegawai, seperti pegawai dengan lulusan keguruan olahraga ditempatkan pada bagian surat menyurat serta pegawai lulusan sarjana hukum ditempatkan pada bagian desain kemasan, maka ilmu yang sudah diterima dijenjang pendidikan belum dimaksimalkan dengan baik pada pekerjaannya, dengan hal tersebut pula pegawai merasa kurang percaya diri pada kemampuan yang dimiliki. Masalah - masalah tersebut jika tidak diselesaikan dengan baik akan berpengaruh pada kinerja pegawai dalam organisasi, di mana pegawai atau sumber daya manusia menjadi salah satu faktor yang mempengaruhi keberhasilan suatu organisasi.

Berdasarkan penyebaran kuesioner yang dilakukan, masalah - masalah yang terjadi pada organisasi tersebut muncul akibat dari pemimpin yang kurang adil memperlakukan seluruh pegawai seperti, pemimpin lebih memberdayakan pegawai kontrak dengan pegawai yang mempunyai penampilan menarik, sedangkan untuk pegawai kontrak yang dianggap tidak memiliki penampilan yang menarik, jarang dilibatkan dalam kegiatan diluar kantor seperti diminta menjadi MC, dirigen ataupun partisipasi dalam kegiatan tahunan lomba paduan suara serta didukung dengan lemahnya budaya organisasi seperti, beberapa pegawai merasa kurang menerima dukungan dari pimpinan seperti dukungan secara finansial, dimana beberapa pegawai kontrak dilibatkan dalam mengerjakan pekerjaan pegawai negeri hingga diluar jam kerja, namun pegawai kontrak tidak pernah mendapat tunjangan uang lembur. Dinas Perindustrian dan Perdagangan Kota Denpasar memerlukan 
kepemimpinan yang lebih bersifat transformasional dalam usaha pemberdayaan psikologis para pegawainya serta didukung dengan budaya organisasi yang kuat. Scott et al. (2014), berpendapat bahwa perilaku kepemimpinan transformasional dapat mengubah konsep diri pegawai dengan menumbuhkan rasa psikologis pegawai tentang makna dan dampak pekerjaan mereka serta kompetensi dan penentuan nasib sendiri dalam menyelesaikan pekerjaan mereka.

Berdasarkan uraian yang telah dijelaskan diatas menunjukan adanya pengaruh secara langsung maupun tidak langsung dari kepemimpinan transformasional terhadap pemberdayaan psikologis. Penelitian ini ingin mengetahui bagaimana pengaruh kepemimpinan transformasional terhadap pemberdayaan psikologis, baik secara langsung maupun tidak langsung melalui budaya organisasi pada Dinas Perindustrian dan Perdagangan Kota Denpasar. Penelitian ini dilakukan pada Dinas Perindustrian dan Perdagangan Kota Denpasar karena adanya masalah pemberdayaan psikologis pada pegawai.

Kepemimpinan transformasional digambarkan sebagai gaya kepemimpinan yang dapat membangkitkan motivasi pegawai, sehingga dapat berkembang dan mencapai kinerja pada tingkat yang tinggi, melebihi dari apa yang mereka pikirkan sebelumnya (Sonni, 2013). Kepemimpinan transformasional prinsipnya berusaha memotivasi bawahan untuk berbuat lebih baik dari apa yang biasa dilakukan, serta dapat meningkatkan kepercayaan atau keyakinan diri bawahan yang akan berpengaruh terhadap peningkatan kinerja (Subhi, 2014). Kepemimpinan transformasional merupakan kemampuan pemimpin yang menginspirasi para pengikutnya untuk melampaui kepentingan diri sendiri demi keuntungan organisasi 
Ni Made Mas Anindya Sthira Sista, Peran Budaya Organisasi...

(Robbins dan Judge, 2015:249). Birasnav et al. (2011), menambahkan bahwa kepemimpinan transformasional menarik banyak perhatian dalam organisasi karena sangat berpengaruh bagi inovasi organisasi, pembelajaran organisasi dan kreativitas pegawai. Kepemimpinan transformasional merupakan suatu usaha yang dilakukan oleh seorang pemimpin untuk mampu memengaruhi dan mengarahkan seseorang atau kelompok agar dapat mengerjakan kewajiban sesuai dengan wewenang yang telah diberikan oleh pemimpinnya dalam mencapai segala visi dan misi organisasi (Paulsen et al. 2013).

Budaya organisasi adalah tentang bagaimana orang merasa melakukan pekerjaan dengan baik sesuai dengan perilaku, keyakinan dan nilai-nilai dalam suatu organisasi (Wibowo, 2016:15). Budaya organisasi adalah sistem nilai yang diyakini, dipelajari, diterapkan dan dikembangkan oleh semua anggota organisasi dalam mencapai tujuan organisasi (Raf dkk., 2014: 6). Belias dan Koustelios (2014), juga mendefinisikan bahwa budaya organisasi adalah pola berpikir yang dianggap benar atau dugaan yang diterima sebagai dasar untuk mengatasi masalah eksternal dan internal.

Teori yang menjadi acuan dalam penelitian ini adalah teori sosial kognitif. Teori ini dikembangkan oleh Albert Bandura seorang ilmuwan psikologi dari Universitas Stanford, USA. Teori sosial kognitif (Social Cognitive Theory) merupakan penamaan baru dari Teori belajar sosial (Social Learning Theory). Teori sosial kognitif adalah belajar dengan cara mengamati perilaku individu atau sebagian perilaku individu diperoleh sebagai hasil belajar melalui pengamatan atas 
tingkah laku yang ditampilkan oleh orang lain yang dipakai sebagai model (Alwisol,2009:283).

Prinsip dasar dari teori ini adalah adanya pengaruh timbal balik (reciprocal determinism) pada tiga faktor yang ada, yaitu individu, lingkungan dan perilaku (Bandura, 1977:63). Dalam model ini faktor individu (kognitif) memainkan peranan penting, dimana faktor individu (kognitif) yang ditekankan oleh Bandura adalah self-efficacy (Santrock, 2011:235). Keterkaitan antara individu, lingkungan dan perilaku merupakan suatu proses yang berlangsung terus menerus sepanjang manusia/individu hidup dan proses tersebut dapat dimulai dari mana saja, dan akan berakhir di mana saja, tergantung pada sisi mana memandangnya (Ellis, 2008:6). Dalam hal ini, pemimpin sebagai individu dapat mempengaruhi lingkungan organisasi dan selanjutnya lingkungan memiliki keterkaitan dengan perilaku, peristiwa yang terjadi disekitar lingkungan organisasi adalah bentuk dari adanya pengaruh individu atau pemimpinnya, sedangkan perilaku pegawai adalah respon atau jawaban atas pengaruh dari lingkungan tersebut.

Pemberdayaan merupakan suatu proses untuk menjadikan orang menjadi lebih berdaya atau lebih berkemampuan untuk menyelesaikan masalahnya sendiri, dengan cara memberikan kepercayaan dan wewenang sehingga menumbuhkan rasa tanggung jawab (Kadarisma, 2012:415). Spreitzer (1995), mendefinisikan pemberdayaan psikologis sebagai semacam motivasi yang diwujudkan dari empat jenis dimensi yaitu keberartian, mampu, penentuan diri dan dampak. Spreitzer berpendapat bahwa keempat dimensi ini diperlukan untuk membentuk keseluruhan pemberdayaan psikologis dan kurangnya satu dari keempat dimensi ini mengurangi 
Ni Made Mas Anindya Sthira Sista, Peran Budaya Organisasi...

keseluruhan tingkat pemberdayaan yang dirasakan. Pemberdayaan dalam bentuk pemberdayaan psikologis adalah proses motivasi yang membantu untuk meningkatkan perasaan mengenai keyakinan individu tentang dirinya dan motivasi pegawai (Thomas dan Velthouse, 1990:76).

Penelitian ini dilakukan untuk mengetahui hubungan antara variabel kepemimpinan transformasional, budaya organisasi dan pemberdayaan psikologis. Hubungan antara variabel tersebut dapat dilihat ketika perilaku pemimpin dengan gaya kepemimpinan transformasional mampu mendukung budaya organisasi menjadi budaya yang kuat, sehingga akan berpengaruh pada meningkatnya proses pemberdayaan psikologis dalam diri pegawai. Hubungan tersebut juga berkaitan dengan teori sosial kognitif di mana ketika pemimpin dengan gaya kepemimpinan transformasional dapat dijadikan model untuk pegawai dalam belajar melalui pengamatan atas tingkah laku yang ditampilkan oleh pemimpinnya untuk mampu memotivasi dan memberdayakan pegawai agar mencapai tujuan organisasi, maka secara langsung akan mendukung budaya organisasi akan semakin kuat serta pegawai akan memberikan respon baik dengan meningkatkan proses pemberdayaan psikologis dalam dirinya.

Bass et al. (1987), menyatakan bahwa ada hubungan positif dan signifikan antara kepemimpinan transformasional dan pemberdayaan psikologis. Studi yang dilakukan oleh Kurnaz dan Arslan (2011) menunjukkan bahwa pemimpin yang menggunakan gaya kepemimpinan transformasional secara signifikan menghubungkan mereka ke arah psikologis memberdayakan sesama pegawai mereka. Dvir et al. (2002), menyatakan bahwa ada kesan positif dan signifikan dari 
kepemimpinan transformasional pada pemberdayaan psikologis. Studi yang dilakukan Khanmohammadi dan Mohseni (2010), tentang dampak gaya kepemimpinan (transformasional, transaksional) pada pemberdayaan psikologis pegawai menemukan hubungan yang signifikan antara dua gaya kepemimpinan (transformasional dan transaksional) dengan pemberdayaan psikologis. Sebuah rangkuman berbagai hasil penelitian terbaru yang dilakukan oleh Seibert et al. (2011), menunjukkan bahwa kepemimpinan transformasional memiliki pengaruh positif terhadap pemberdayaan psikologis. Berdasarkan hasil dari penelitianpenelitian di atas, maka dapat dirumuskan hipotesis sebagai berikut:

$\mathrm{H}_{1}$ : Kepemimpinan transformasional berpengaruh positif dan signifikan dengan pemberdayaan psikologis.

Karakteristik budaya yang positif sangat penting untuk inovasi, dan kreativitas, dengan mempertimbangkan visi, misi, dan nilai-nilai organisasi serta budaya yang disusun dan dilaksanakan oleh pemimpin (Szczepanska-Woszczyna, 2015). Hubungan antara kepemimpinan transformasional dan budaya organisasi, menunjukkan bahwa kepemimpinan transformasional secara langsung mempengaruhi budaya organisasi (Lee dan Cho, 2018). Bass dan Avolio (1993) menyatakan bahwa kepemimpinan transformasional akan membentuk budaya organisasi yang menunjang kinerja individu dan organisasi, yakni budaya organisasi yang tanggap terhadap lingkungan, menghargai pegawai, mendorong inovasi dan kreativitas serta menyatukan upaya demi kepentingan organisasi. Block (2003), meneliti adanya hubungan antara kepemimpinan transformasional dan budaya organisasi serta menemukan bahwa gaya kepemimpinan transformasional 
Ni Made Mas Anindya Sthira Sista, Peran Budaya Organisasi...

langsung secara positif dan signifikan mempengaruhi pegawai terhadap budaya organisasi. Para pemimpin membangun tim, menciptakan kesatuan, dan menyelesaikan perselisihan di tingkat kelompok, dan pada akhirnya pemimpin membangun budaya dan menciptakan perubahan dalam organisasi (Nurjanah, 2008). Berdasarkan hasil dari penelitian-penelitian di atas, maka dapat dirumuskan hipotesis sebagai berikut:

$\mathrm{H}_{2}$ : Kepemimpinan transformasional berpengaruh positif dan signifikan dengan budaya organisasi.

Johnson (2009), berpendapat bahwa budaya organisasi membentuk organisasi dan memberikan pemahaman yang lebih baik, seperti pemberdayaan dan telah menyarankan bahwa budaya organisasi yang tepat meningkatkan proses pemberdayaan psikologis dalam organisasi. Budaya di mana pegawai yang berpartisipasi dalam organisasi cenderung menciptakan kondisi yang menguntungkan dalam peningkatan pemberdayaan psikologis (Pareek, 2002:173). Sotirofski (2014), yang menyatakan bahwa budaya organisasi yang mendukung untuk berubah adalah salah satu faktor penting yang dapat mempengaruhi pemberdayaan psikologis. Hasil penelitian yang telah dilakukan oleh Husein (2018), menunjukan bahwa budaya organisasi memiliki pengaruh langsung secara positif dan signifikan terhadap pemberdayaan psikologis. Hatami (2012), menyatakan bahwa pegawai yang diberdayakan akan menunjukkan komunikasi yang lebih baik dan budaya organisasi yang lebih kuat. Berdasarkan hasil dari penelitian-penelitian di atas, maka dapat dirumuskan hipotesis sebagai berikut:

$\mathrm{H}_{3}$ : Budaya Organisasi berpengaruh positif dan signifikan dengan pemberdayaan psikologis. 
Rabindra et al. (2017), menemukan bahwa budaya organisasi secara signifikan memediasi hubungan antara kepemimpinan transformasional dan pemberdayaan psikologis. Abdul Karim (2017), menyatakan bahwa budaya organisasi memediasi pengaruh kepemimpinan transformasional terhadap pemberdayaan psikologis. Hasil penelitian yang telah dilakukan oleh Husein (2018), menunjukan bahwa budaya organisasi dapat memediasi pengaruh kepemimpinan transformasional terhadap pemberdayaan psikologis. Penelitian Sotirofski (2014), yang menyatakan bahwa budaya organisasi yang mendukung untuk berubah adalah salah satu faktor penting yang dapat mempengaruhi pemberdayaan psikologis. Hubungan yang signifikan antara kepemimpinan transformasional dan budaya organisasi yang menunjukkan bahwa kepemimpinan transformasional secara langsung memberikan dorongan untuk membawa budaya organisasi yang kompetitif dan berorientasi kinerja (Song et al., 2012). Berdasarkan hasil dari penelitian-penelitian di atas, maka dapat dirumuskan hipotesis sebagai berikut:

$\mathrm{H}_{4}$ : Budaya Organisasi berpengaruh secara signifikan dalam memediasi pengaruh kepemimpinan transformasional terhadap pemberdayaan psikologis.

\section{METODE PENELITIAN}

Lokasi penelitian ini dilakukan pada Dinas Perindustrian dan Perdagangan Kota Denpasar, yang beralamat di Jalan Majapahit No.1 Gedung Graha Sewaka Dharma Lt. III Denpasar. Alasan dilakukannya penelitian pada Dinas ini, karena ditemukan masalah mengenai pemberdayaan psikologis, dimana diduga pemberdayaan psikologis dipengaruhi oleh kepemimpinan transformasional dan 
Ni Made Mas Anindya Sthira Sista, Peran Budaya Organisasi...

budaya organisasi, selain itu pemilihan lokasi tersebut juga dikarenakan tersedianya data yang memadai dan mampu untuk diolah.

Populasi yang digunakan dalam penelitian ini adalah seluruh pegawai kontrak yang sudah bekerja minimal 1 tahun yang berjumlah 50 orang. Data jumlah pegawai kontrak yang sudah bekerja minimal 1 tahun pada Dinas Perindustrian dan Perdagangan Kota Denpasar tahun 2018 ditunjukan pada Tabel 1.

Tabel 1.

Data Jumlah Pegawai Kontrak Dinas Perindustrian dan Perdagangan Kota Denpasar Tahun 2018

\begin{tabular}{clc}
\hline NO & \multicolumn{1}{c}{ Bidang } & $\begin{array}{c}\text { Jumlah Pegawai } \\
\text { (orang) }\end{array}$ \\
\hline 1. & Sekretariat & 7 \\
2. & $\begin{array}{l}\text { Bidang Industri Kerajinan, Aneka, dan } \\
\text { Sandang }\end{array}$ & 12 \\
& $\begin{array}{l}\text { Bidang Industri Logam, Mesin, Elektronika } \\
\text { 3. }\end{array}$ & 9 \\
Telematika, dan Agro & Bidang Perdagangan & 10 \\
5. & Bidang Metrology dan Tertib Niaga & 12 \\
& Total & $\mathbf{5 0}$ \\
\hline
\end{tabular}

Metode pengambilan sampel dalam penelitian ini menggunakan sampling jenuh, dimana semua anggota populasi dijadikan sebagai sampel. Berdasarkan uraian diatas, besarnya sampel yang diteliti berjumlah 50 orang pegawai kontrak yang sudah bekerja minimal 1 tahun.

Teknik analisis data yang digunakan dalam penelitian ini adalah analisis jalur (Path Analysis).

Persamaan Sub-struktural 1

$$
\mathrm{M}=\beta_{1} \mathrm{X}+\mathrm{e}_{1}
$$

Persamaan Sub-struktural 2

$$
\mathrm{Y}=\beta_{2} \mathrm{X}+\beta_{3} \mathrm{M}+\mathrm{e}_{2}
$$


Keterangan:

$$
\begin{array}{ll}
\mathrm{Y} & =\text { Pemberdayaan psikologis } \\
\mathrm{X} & =\text { Kepemimpinan transformasional } \\
\mathrm{M} & =\text { Budaya organisasi } \\
\beta_{1}, \beta_{2}, \beta_{3} & =\text { Koefisien regresi variabel } \\
\mathrm{e} & =\text { Error }
\end{array}
$$

\section{HASIL DAN PEMBAHASAN}

Responden pada penelitian ini berusia 21-30 tahun dengan persentase sebanyak 64 persen, kemudian berusia 31-40 tahun dengan persentase sebanyak 30 persen dan berusia $>40$ sebesar 6 persen. Responden pada penelitian ini didominasi dengan responden yang berusia 21-30 tahun, hal tersebut dikarenakan usia tersebut merupakan usia yang tergolong masih muda dan berpeluang dalam mengembangkan potensi yang dimiliki agar lebih baik lagi. Dengan demikian bahwa pegawai kontrak pada Dinas Perindustrian dan Perdagangan Kota Denpasar berada pada usia produktif.

Persentase jumlah responden yang berjenis kelamin laki-laki sebesar 56 persen dan persentase responden yang berjenis kelamin perempuan sebesar 44 persen. Pada penelitian ini responden laki-laki yang mendominasi, hal ini dikarenakan jumlah pegawai kontrak yang berjenis kelamin laki-laki lebih diperlukan terutama pada bidang industri dan tertib niaga karena dianggap lebih memiliki kemampuan dalam menggunakan peralatan mesin.

Tingkat pendidikan terakhir responnden yaitu pada tingkat pendidikan SMA sebanyak 12 persen, kemudian tingkat pendidikan S1 sebesar 82 persen dan yang terakhir tingkat pendidikan S2 sebanyak 6 persen. Responden dengan tingkat pendidikan S1 yang mendominasi yang artinya pegawai kontrak dengan tingkat 
Ni Made Mas Anindya Sthira Sista, Peran Budaya Organisasi...

pendidikan S1 rata-rata memiliki peluang yang lebih besar untuk diterima sebagai pegawai tenaga administrasi, dimana pegawai yang memiliki pendidikan S1 dianggap lebih mampu menjalankan tugas yang diberikan jika dilihat dari latar belakang pendidikan.

Responden yang bekerja 1-5 tahun sebanyak 66 persen, dan 6-10 tahun sebanyak 34 persen. Responden dengan masa kerja 1-5 tahun mendominasi, hal tersebut dikarenakan pegawai kontrak lebih memilih mencari pengalaman kerja untuk mengembangkan karirnya. Pegawai kontrak belum tentu sanggup bertahan tanpa adanya suasana kerja yang baru seperti mutasi, maka pegawai kontrak lebih memilih mencari peluang pekerjaan yang lebih baik atau dengan mengikuti CPNS.

Perhitungan koefisien path dilakukan dengan analisis regresi melalui software SPSS 22.0 for Windows, diperoleh hasil yang ditunjukan pada Tabel 2.

Tabel 2.

Hasil Analisis Jalur Persamaan Regresi 1

\begin{tabular}{cccc}
\hline Model & R Square & $\begin{array}{c}\text { Standardized Coeffcients } \\
\text { Beta }\end{array}$ & Sig. \\
\hline Kep. Transformasional & 0,553 & 0,744 & 0,000 \\
\hline
\end{tabular}
Sumber: Data diolah, 2018

Berdasarkan hasil analisis jalur regresi 1 seperti yang disajikan pada Tabel 2, maka persamaan strukturalnya adalah sebagai berikut:

$$
\begin{array}{r}
M=\beta_{1} X+e_{1} \ldots \ldots \ldots \ldots \ldots . \\
M=0,744 X+e_{1}
\end{array}
$$

Nilai $\beta_{1}$ adalah sebesar 0,744 memiliki arti bahwa kepemimpinan transformasional berpengaruh positif terhadap budaya organisasi. 
Tabel 3.

Hasil Analisis Jalur Persamaan Regresi 2

\begin{tabular}{cccc}
\hline Model & R Square & $\begin{array}{c}\text { Standardized Coeffcients } \\
\text { Beta }\end{array}$ & Sig. \\
\hline Kepemimpinan Transformasional & 0,765 & 0,328 & 0,000 \\
Budaya Organisasi & 0,765 & 0,603 & 0,000 \\
\hline Sumber: Data diolah, 2018 & &
\end{tabular}

Berdasarkan hasil analisis jalur regresi 2 seperti yang disajikan pada Tabel 3, maka persamaan strukturalnya adalah sebagai berikut:

$$
\begin{array}{r}
\mathrm{Y}=\beta_{2} \mathrm{X}+\beta_{3} \mathrm{M}+\mathrm{e}_{2} \ldots \ldots \ldots \ldots \ldots \ldots \ldots \ldots \\
\mathrm{Y}=0,328 \mathrm{X}+0,603 \mathrm{M}+\mathrm{e}_{2}
\end{array}
$$

Nilai $\beta_{2}$ adalah sebesar 0,328 memiliki arti bahwa kepemimpinan transformasional berpengaruh positif terhadap pemberdayaan psikologis. Nilai $\beta_{3}$ adalah sebesar 0,603 memiliki arti bahwa budaya organisasi berpengaruh positif terhadap pemberdayaan psikologis.

Berdasarkan model sub struktur 1 dan sub struktur 2, maka dapat disusun model diagram jalur akhir. Sebelum menyusun model diagram jalur akhir, terlebih dahulu dihitung standar eror sebagai berikut :

$$
\begin{array}{r}
\mathrm{e}=\sqrt{1-R 1^{2}} \ldots \ldots \ldots \ldots \ldots \ldots \ldots \\
e_{1}=\sqrt{1-R 1^{2}}=\sqrt{1-0,553}=0,668
\end{array}
$$

(sebesar 66,8\% variabel kepemimpinan transformasional tidak mampu menjelaskan variabel budaya organisasi).

$$
\begin{aligned}
& e_{2}=\sqrt{1-R 2^{2}} \ldots \ldots \ldots \ldots \\
& =\sqrt{1-0,765}=0,484
\end{aligned}
$$


Ni Made Mas Anindya Sthira Sista, Peran Budaya Organisasi...

(sebesar 48,8\% variabel kepemimpinan transformasional dan budaya organisasi tidak mampu menjelaskan variabel pemberdayaan psikologis).

Berdasarkan perhitungan pengaruh error (e), didapatkan hasil pengaruh error $\left(e_{1}\right)$ sebesar 0,668 dan pengaruh error $\left(e_{2}\right)$ sebesar 0,484 .

Hasil koefisien determinasi total adalah sebagai berikut :

$$
\begin{aligned}
R_{m}^{2} & =1-\left(e_{1}\right)^{2}\left(e_{2}\right)^{2} \ldots \ldots \ldots . \\
& =1-(0,668)^{2}(0,484)^{2} \\
& =1-(0,446)(0,234) \\
& =1-0,104=0,895
\end{aligned}
$$

Nilai determinasi total sebesar 0,895 mempunyai arti bahwa 89,5\% variasi pemberdayaan psikologis dipengaruhi oleh variasi kepemimpinan transformasional dan budaya organisasi, sedangkan sisanya sebesar $10,5 \%$ dijelaskan oleh faktor lain yang tidak dimasukkan ke dalam model.

Berdasarkan hasil analisis pengaruh kepemimpinan transformasional terhadap budaya organisasi nilai Sig. $\mathrm{t}$ sebesar 0,000 dengan nilai koefisien beta 0,744. Nilai Sig. t $0,000<0,05$ mengindikasikan bahwa $\mathrm{H}_{0}$ ditolak dan $\mathrm{H}_{1}$ diterima. Hasil ini mempunyai arti bahwa Hipotesis diterima yang berarti kepemimpinan transformasional berpengaruh positif dan signifikan terhadap budaya organisasi.

Berdasarkan hasil analisis pengaruh kepemimpinan transformasional terhadap pemberdayaan psikologis diperoleh nilai Sig. $t$ sebesar 0,000 dengan nilai koefisien beta 0,328 . Nilai Sig. t $0,000<0,05$ mengindikasikan bahwa bahwa $\mathrm{H}_{0}$ ditolak dan $\mathrm{H}_{1}$ diterima. Hasil ini mempunyai arti bahwa Hipotesis diterima yang 
berarti kepemimpinan transformasional berpengaruh positif dan signifikan terhadap pemberdayaan psikologis.

Berdasarkan hasil analisis pengaruh budaya organisasi terhadap pemberdayaan psikologis diperoleh nilai Sig. t sebesar 0,000 dengan nilai koefisien beta 0,603 . Nilai Sig. t $0,000<0,05$ mengindikasikan bahwa $\mathrm{H}_{0}$ ditolak dan $\mathrm{H}_{1}$ diterima. Hasil ini mempunyai arti bahwa Hipotesis diterima yang berarti budaya organisasi berpengaruh positif dan signifikan terhadap pemberdayaan psikologis.

Perhitungan pengaruh antar variabel dirangkum dalam Tabel 4 sebagai berikut.

Tabel 4.

Pengaruh Langsung dan Pengaruh Tidak Langsung serta Pengaruh Total Kepemimpinan Transformasional (X), Budaya Organisasi (M), dan Pemberdayaan Psikologis (Y)

\begin{tabular}{cccc}
\hline $\begin{array}{c}\text { Pengaruh } \\
\text { Variabel }\end{array}$ & $\begin{array}{c}\text { Pengaruh } \\
\text { Langsung }\end{array}$ & $\begin{array}{c}\text { Pengaruh Tidak Langsung Melalui } \\
\text { Budaya Organisasi } \\
(\mathbf{M})(\boldsymbol{\beta 1} \mathbf{~} \boldsymbol{\beta 3})\end{array}$ & $\begin{array}{c}\text { Pengaruh } \\
\text { Total }\end{array}$ \\
\hline $\mathrm{X} \rightarrow \mathrm{M}$ & 0,744 & - & 0,744 \\
$\mathrm{X} \rightarrow \mathrm{Y}$ & 0,328 & 0,448 & 0,776 \\
$\mathrm{M} \rightarrow \mathrm{Y}$ & 0,603 & - & 0,603 \\
\hline Sumber: Data diolah, 2018 & &
\end{tabular}

Uji Sobel merupakan alat analisis untuk menguji signifikansi dari hubungan tidak langsung antara variabel eksogen dengan variabel endogen yang dimediasi oleh variabel mediator. Uji Sobel dirumuskan dengan persamaan berikut dan dapat dihitung dengan menggunakan aplikasi Microsoft Excel 2007. Taraf nyata alpha 0,05 dan Z Tabel 1,96.

$$
\begin{aligned}
& Z=\frac{a b}{\sqrt{b^{2} s_{a}^{n}+a^{2} s_{b}^{n}+s_{a}^{2} s_{b}^{n}}} . \\
& \operatorname{Sig}=(1-\operatorname{NORMDIST}(Z))+2))
\end{aligned}
$$


Keterangan:

$$
\begin{aligned}
& a=0,744 \\
& s_{a}=0,262 \\
& b=0,603 \\
& S_{b}=0,065
\end{aligned}
$$

$$
\begin{aligned}
& Z=\frac{0,744,0,603}{\sqrt{(0,603)^{2}(0,262)^{2}+(0,744)^{2}(0,065)^{2}+(0,262)^{2}(0,065)^{2}}} \\
& Z=\frac{0,4486}{\sqrt{0,0250+0,0023+0,0003}} \\
& Z=\frac{0,4486}{\sqrt{0,0276}} \\
& Z=\frac{0,4496}{0,1661}
\end{aligned}
$$$$
\mathbf{Z}=\mathbf{2 , 7 0 0 7}
$$

Tabel 5.

Hasil Uji Sobel

\begin{tabular}{rc}
\hline Nilai Z & Sig \\
\hline 2,7007 & 0,000 \\
\hline Sumber: Data diolah, 2018 &
\end{tabular}

Berdasarkan hasil Uji Sobel pada Tabel 5. menunjukkan bahwa hasil tabulasi $\mathrm{Z}=2,7007>1,96$ dengan tingkat signifikansi $0,000<0,05$ yang berarti variabel mediator yakni Budaya Organisasi dinilai secara signifikansi memediasi pengaruh antara Kepemimpinan Transformasional terhadap Pemberdayaan Psikologis.

Berdasarkan hasil yang diperoleh nilai koefisien beta positif sebesar 0,328 dengan tingkat signifikansi 0,000 (kurang dari 0,05) yang berarti variabel kepemimpinan transfomasional berpengaruh positif dan signifikan terhadap pemberdayaan psikologis, hal ini berarti semakin baik seorang pemimpin menerapkan gaya kepemimpinan transformasionalnya maka semakin tinggi 
pemberdayaan psikologis yang dirasakan oleh pegawai dalam organisasi. Hasil penelitian ini mendukung penelitian sebelumnya yang dilakukan oleh Bass et al. (1987), Kurnaz dan Arslan (2011) Khanmohammadi dan Mohseni (2010), dan Seibert et al. (2011) yang menyatakan bahwa kepemimpinan transformasional berpengaruh positif dan signifikan terhadap pemberdayaan psikologis.

Berdasarkan hasil pengujian hipotesis, pengaruh kepemimpinan transformasional terhadap budaya organisasi dengan hasil Signifikansi 0,000 (kurang dari 0,05) serta koefisien beta sebesar 0,744 yang menunjukkan bahwa kepemimpinan transformasional berpengaruh positif dan signifikan terhadap budaya organisasi, hal ini berarti jika pemimpin dengan gaya kepemimpinan transformasional mampu mendorong dan memotivasi pegawai untuk mencapai tujuan organisasi maka akan berpengaruh pada semakin kuat budaya organisasinya. Hasil penelitian ini mendukung penelitian sebelumnya yang dilakukan oleh Block (2003), Lee dan Cho (2018), Nurjanah (2008) dan Szczepanska-Woszczyna (2015) yang menyatakan bahwa kepemimpinan transformasional berpengaruh positif dan signifikan terhadap budaya organisasi.

Berdasarkan hasil yang diperoleh nilai koefisien beta positif sebesar 0,603 dengan tingkat signifikansi 0,000 (kurang dari 0,05) yang berarti variabel budaya organisasi berpengaruh positif dan signifikan terhadap pemberdayaan psikologis, hal ini berarti semakin kuat budaya organisasi pada Dinas Perindustrian dan Perdagangan Kota Denpasar akan berpengaruh pada semakin meningkatnya pemberdayaan psikologis yang dirasakan oleh pegawai dalam organisasi. Hasil penelitian ini mendukung penelitian sebelumnya yang dilakukan oleh Husein, 
Ni Made Mas Anindya Sthira Sista, Peran Budaya Organisasi...

(2018), Johnson (2009), Hatami (2012), Sotirofski (2014) dan Pareek (2002) yang menyatakan bahwa budaya organisasi berpengaruh positif dan signifikan terhadap pemberdayaan psikologis.

Pengujian hipotesis peran budaya organisasi memediasi pengaruh kepemimpinan transformasional terhadap pemberdayaan psikologis menggunakan Uji Sobel dan memperoleh hasil Z sebesar $2,70(>1,96)$ dengan tingkat nilai signifikansi $0,000(<0,05)$ yang mengindikasikan bahwa budaya organisasi secara positif dan signifikan memediasi pengaruh kepemimpinan transformasional terhadap pemberdayaan psikologis, hal ini berarti ketika perilaku pemimpin dengan gaya kepemimpinan transformasional mampu mendukung budaya organisasi menjadi budaya yang kuat, sehingga akan berpengaruh pada meningkatnya proses pemberdayaan psikologis dalam diri pegawai. Hasil penelitian ini sesuai dengan penelitian sebelumnya yang dilakukan oleh Rabindra et al. (2017), bahwa budaya organisasi secara positif dan signifikan memediasi hubungan antara kepemimpinan transformasional dan pemberdayaan psikologis. Abdul Karim (2017), mengatakan bahwa budaya organisasi memediasi pengaruh kepemimpinan transformasional terhadap pemberdayaan psikologis.

Berdasarkan penelitian yang telah dilakukan dapat diketahui bahwa secara teoritis, penelitian ini mendukung beberapa teori yang telah ada sebelumnya. Penelitian ini diharapkan dapat menjadi suatu hal baru untuk penelitian yang berhubungan dengan variabel pemberdayaan psikologis, kepemimpinan transformasional, dan budaya organisasi. Pengolahan data dilakukan dengan teknik analisis jalur (path analysis) untuk memperkirakan hubungan antara variabel- 
variabel yang telah ditetapkan sebelumnya berdasarkan teori. Penelitian ini juga menggunakan uji sobel untuk menguji kekuatan pengaruh tidak langsung variabel kepemimpinan transformasional $(\mathrm{X})$ terhadap pemberdayaan psikologis (Y) melalui variabel budaya organisasi (M). Hasil penelitian ini diharapkan dapat digunakan untuk memperkaya referensi yang berkaitan dengan pemberdayaan psikologis, kepemimpinan transformasional, dan budaya organisasi.

Hasil penelitian ini digunakan sebagai masukan bagi Dinas Perindustrian dan Perdagangan Kota Denpasar untuk dapat memperbaiki perilaku pemimpin dengan gaya kepemimpinan transformasional yang mampu mendukung budaya organisasi menjadi budaya yang kuat, sehingga akan berpengaruh pada meningkatnya proses pemberdayaan psikologis dalam diri pegawai.

\section{SIMPULAN DAN SARAN}

Kepemimpinan transformasional berpengaruh positif dan signifikan terhadap pemberdayaan psikologis yang artinya semakin baik gaya kepemimpinan yang ada pada organisasi, maka semakin baik proses pemberdayaan psikologis yang dirasakan oleh pegawai.

Kepemimpinan transformasional berpengaruh positif dan signifikan terhadap budaya organisasi yang artinya semakin baik gaya kepemimpinan yang ada pada organisasi, maka akan memperkuat budaya organisasinya. Budaya Organisasi berpengaruh positif dan signifikan terhadap pemberdayaan psikologis yang artinya semakin kuat budaya yang ada dalam suatu organisasi, maka semakin baik proses pemberdayaan psikologis yang dirasakan oleh pegawai. 
Budaya organisasi memediasi pengaruh kepemimpinan transformasional terhadap pemberdayaan psikologis yang artinya jika perilaku pemimpin dengan gaya kepemimpinan transformasional yang mampu mendukung budaya organisasi menjadi budaya yang kuat, sehingga akan berpengaruh pada meningkatnya proses pemberdayaan psikologis dalam diri pegawai.

\section{REFERENSI}

Bass and Avolio. (1990). Developing Transformational Leadership and Beyond. Journal of European Industrial Training, 14(5), pp.21-27.

Bass, B.M., B.J, Avolio., D.I, Jung, and Y. Berson. (2003). Predicting unit performance by assessing transformational and transactional leadership, Journal of Applied Psychology, 88(2), pp.207-218.

Birasnav, M. S. Rangnekar and A. Dalpati. (2011). Transformasional leadership and human capital benefits: the role of knowledge management. Leadership \& Organization Development Journal, 32(2), pp.106-126.

Block, L. (2003). The leadership-culture connection: An exploratory investigation. Leadership \& Organization Development Journal, 24(6), pp.318-334.

Boudrias, J. S., A. J. Morin, and D. Lajoie. (2014). Directionality of the associations between psychological empowerment and behavioural involvement: A longitudinal autoregressive cross-lagged analysis. Journal of Occupational and Organizational Psychology, 87(3), pp.437-463.

Dvir, T., Eden, D., B.J. Avolio, and B. Shamir. (2002). Impact of transformational leadership on follower development and performance: a field experiment. Academy of Management Journal, 45(4), pp.735-744.

Edalatian Shahriari, J., J. Maleki., P. Koolivand, and M. Meyvand. (2013). The study of the relationship between organizational structure and psychological empowerment among the staffs in Ministry of Economic Affairs and Finance. European Online Journal of Natural and Social Sciences, 2(3), pp.330-338.

Hatami, S. (2012). The Study of Relationship between Organizational Culture and Empowerment (Case Study in Private Banks in Kermanshah). Journal of Basic and Applied Scientific Research, 2(4), pp.3623-3630. 
Kurnaz, M. and A. Arslan. (2011). Praxeological analysis of the teaching conditions of the energy concept. Cypriot Journal of Educational Sciences, 5(4), pp. 233-242.

Lee, K. and Cho, W.(2018). The Relationship between Transformational Leadership of Immediate Superiors, Organizational Culture, and Affective Commitment in Fitness Club Employees. Sport Mont Journal, 16(1), pp.1519.

MacIntosh, Eric W. (2010). The influence of Organizational Culture on Job Satisfaction and Intention to Leave. Journal of Sport Management Review, 13, pp.106-117.

Maulizar, Musnadi, Yunus. (2012). Pengaruh Kepemimpinan Transaksional dan Transformasional terhadap Kinerja Karyawan Bank Syariah Mandiri Cabang Banda. Jurnal Ilmu Manajemen, 1(1), pp. 1-13.

Paulsen, Neil., Victor J. Callan., Oluremi Ayoko, and Diana Saunders. (2013). Transformational leadership and innovation in an R\&D organization experiencing major change. Journal of Organizational Change Management, 26(3), pp.595-610.

Raf, A.G., Desmiyanti, dan Wiguna, M. (2014). Pengaruh Gaya Kepemimpinan, Budaya Organisasi, Motivasi Kerja dan Lingkungan Kerja terhadap Kinerja Akuntan Pemerintah (Studi Empiris pada Perwakilan BPKP Provinsi Riau). Jurnal Online Mahasiswa FE Universitas Riau, 1(2), hal.1-15.

Rabindra K. Pradhan., P. Madhusmita, and Lalatendu K. Jena, (2017). Transformational leadership and psychological empowerment: The mediating effect of organizational culture in Indian retail industry. Journal of Enterprise Information Management, 30(1), pp.82-95

Scott B. Dust., Christian J. Resick, and Mary B. Mawritz. (2014). Transformational leadership, psychological empowerment, and the moderating role of mechanistic-organic contexts. Journal of Organizational Behavior, J. Organiz. Behav, 35, pp.413-433.

Seibert, S.E., G. Wang, and S.H. Courtright. (2011). Antecedents and consequences of psychological and team empowerment in organizations: a meta-analytic review. Journal of Applied Psychology, 96( 5), pp.981-1003.

Sotirofski, K. (2014). Albania organizational culture impact on psychological empowerment of academic staff. European Journal of Sustainable Development, 3(2), pp.119-124. 
Ni Made Mas Anindya Sthira Sista, Peran Budaya Organisasi...

Spreitzer, G.M. (1995). Psychological empowerment in the workplace: dimensions, measurement, and validation. Academy of Management Journal, 38(5), pp.1442-1465.

Subhi, E. R. (2014). Pengaruh Kepemimpinan Transformasional Terhadap Kinerja Karyawan dengan Penghargaan sebagai Variabel Moderating. Jurnal Ilmu \& Riset Manajemen, 3(2), hal.1-18.

Sonni, J. A. (2013). Pengaruh Gaya Kepemimpinan Transformasional Dan Transaksional Terhadap Kinerja Organisasi Dengan Budaya Organisasi Sebagai Variabel Pemoderasi (Studi Empiris Pada Perusahaan Perbankan Di Kota Padang). Jurnal Akuntansi, 1(1), h:1-24.

Stander, M. W. and S. Rothmann. (2010). Psychological empowerment, job insecurity and employee engagement. South African Journal of Industrial Psychology, 36(1), pp.1-8.

Szczepańska-Woszczyna, K. (2015). Leadership and organizational culture as the normative influence of top management on employee's behaviour in the innovation process. Procedia Economics and Finance, 34(2), pp.396-402. 